Lau, S. H. et al. Effectiveness of Online Training for Rural Entrepreneurs During a Global Pandemic

\title{
Effectiveness of Online Training for Rural Entrepreneurs During a Global Pandemic
}

Lau Sie Hoe ${ }^{1}$, Mohd Ariff Zabidi Manja², Vloreen Nity Mathew ${ }^{3}$, Adeline Engkamat ${ }^{1}$, Zalina Ibrahim ${ }^{3}$ \& Ahmad Lutfi Anis ${ }^{* 4}$

*Corresponding Author: lutfianis@uitm.edu.my

1. Faculty of Computer and Mathematical Sciences, Universiti Teknologi MARA Cawangan Sarawak, Kota Samarahan, Malaysia

2. Faculty of Plantation and Agrotechnology, Universiti Teknologi MARA Cawangan Sarawak, Kota Samarahan, Malaysia

3. Faculty of Business and Management, Universiti Teknologi MARA Cawangan Sarawak, Kota Samarahan, Malaysia

4. Faculty of Applied Sciences, Universiti Teknologi MARA Cawangan Sarawak, Kota Samarahan, Malaysia

\section{Abstract}

The ability of rural entrepreneurs to cope with the COVID-19 pandemic greatly depends on their knowledge of Information and Communication Technology (ICT) to support online business. In this study, online surveys were conducted to assess the readiness and acceptance of rural entrepreneurs in adopting to the pandemic using the available technologies. Data collected were analyzed by descriptive and inferential statistics using ANOVA. Online training modules were designed based on their specific needs. Although participants indicated that their frequency and skills of using the electronic devices or applications had generally increased or improved after the training, the increment was not statistically significant $(\alpha=0.05)$. This indicated that while the participants, to some extent, benefited from the online training provided, there has not been a significant impact on them.

Keywords: entrepreneurs, online training, pandemic, COVID-19, skills

\section{Introduction}

With the advancement of digital technology and its recognized importance in a developing economy, Malaysian entrepreneurs have been encouraged to embrace the digital economy. One of the steps taken is to equip entrepreneurs, particularly those in rural areas, with Information and Communication Technology (ICT) knowledge and skills to pursue bigger opportunities in online business. Entrepreneurs' ability to capitalize on the digital economy, particularly rural entrepreneurs, greatly depends on their ability to acquire sufficient ICT knowledge to support online business. Communities in rural areas in the state of Sarawak, 
Lau, S. H. et al. Effectiveness of Online Training for Rural Entrepreneurs During a Global Pandemic

Malaysia, face a bigger challenge compared to the urban populations as there are limited mechanisms to ensure that remote rural populations will be able to receive the same benefits due to the limited infrastructure and amenities available (Gnaniah et al., 2004; Horn \& Rennie, 2018). While the development of digital infrastructure is aggressively planned and implemented as part of the Sarawak Digital Economy Strategy, awareness, knowledge, and skills to support its usage may still be lacking among the rural entrepreneurs.

One of many projects proposed in 2019 to complement the Sarawak government's efforts was to identify the problems and obstacles faced by rural entrepreneurs in the Samarahan Division of Sarawak; devise and provide ICT training module relevant to the needs of the entrepreneurs. The project's main activities were to engage with rural entrepreneurs through training programs organized at the Universiti Teknologi MARA (UiTM) campus. After establishing a baseline study that involved focus group discussions, in-depth interviews and collection of qualitative data using the purposive sampling method, training courses were to be designed based on the findings. ICT and entrepreneurial courses were planned to be conducted over a 6-month duration. Levels of knowledge and usage of ICT among the sample communities were to be evaluated and analyzed via descriptive and influential statistics in the subsequent stage of the project. However, the unforeseen COVID-19 pandemic across the world in early 2020 resulted in the implementation of lockdowns and months of movement control order (MCO) by the Malaysian government in its effort to curb the spread of the Coronavirus. The MCO measures include restrictions on movement, assembly and international travel and the closure or limited operations of businesses, industries, government offices, and educational institutions. The situation has disrupted our pursuant of face-to-face training programs as earlier planned. As such, the training modules were redesigned to cater for online learning.

Online learning has emerged as a preferred environment for teaching and learning in entrepreneurship training (AlDahdouh, 2019; Altowairiki, 2021; Batmang et al., 2021; Demosthenous, Panaoura, \& Eteokleous, 2020; Hu \& Huang, 2022; Kilincer, 2021; Korkmaz \& Toraman, 2020; Paudyal \& Rana, 2021; K. Selvarajah \& Hussin, 2017; Thompson \& McDowell, 2019; Xhelili et al., 2021). Apart from substantial cost reduction and the ability to reach learners anywhere and anytime, online learning plays a crucial role in reaching entrepreneurs throughout urban, suburban and rural Malaysia. As a result of the COVID-19 social distancing efforts, there has been a large-scale transition to online learning (Atilgan, \& Tukel, 2021; EISaheli-Elhage, 2021; Govindarajan \& Srivastava, 2020; Kara, 2021; Kibici, 2021; Restuati et al., 2021). The components of such a carefully designed online experience include learning methodologies, contexts, tools and simulators and support systems for digital learning (Sousa et al., 2019). On the other hand, online learning may pose a challenge to entrepreneurs, particularly rural entrepreneurs, due to various reasons. Limited IT infrastructure, lack of technical skills, fear of technology, negative attitudes towards technology usage, and lack of technical support, including internet coverage and accessibility, challenge the implementation of online learning (Ali \& Magalhaes, 2008; Kalimullina et al., 2021; Maphalala et al., 2021; Matarirano et al., 2021; Welsh et al., 2003; Williams et al., 2021).

Adopting and implementing advanced technologies by businesses has many advantages, namely, the value-added creativity (Hitt \& Brynjolfsson, 1996; Smith \& Correa 2005), digitization of operations (Caldeira et al., 2012; Mukhopadhyay et al., 1995), and the creation 
Lau, S. H. et al. Effectiveness of Online Training for Rural Entrepreneurs During a Global Pandemic

of social businesses, which can be significant for small and medium scale business entrepreneurs (Turkina, 2018). However, small businesses are normally restricted by a lack of time, information and knowledge, and budget, which hinder the adoption of the latest technologies and limits their ability to withstand market competition (Laudon \& Laudon, 2019). Abdul Rashid (2016) reported on the analysis of the capability of ICT among rural women entrepreneurs in Malaysia. While the rural communities are aware of the benefits and importance of technology for their businesses, most do not fully apply internet technology in their lives. They prefer simple and easy technologies compared to advanced technologies that are perceived as difficult but could be beneficial. Although prior studies indicated that small businesses adopt or are willing to utilize advanced technologies at a slow pace under normal circumstances, it can suddenly become imminent when faced with unusual situations such as during the COVID-19 pandemic (Akpan et al., 2020).

With the implementation of online training, under unusual circumstances such as a global pandemic, there is a change in the initial perspective of the study and poised to answer different critical questions. The scope of the survey becomes more inclined towards questions relating to the sustainability of rural entrepreneurs during the tough pandemic. It is not just about the effect of the MCO on businesses in terms of income but also the mode of business and readiness of the rural entrepreneurs to adopt to the pandemic situation using technologies available to them. This information is important in designing the training modules required including the suitable training platforms that can enable the rural entrepreneurs to cope with online learning. Therefore, the study intends to answer the following research questions:

- What are the challenges faced by rural entrepreneurs during the pandemic and how they tried to overcome these challenges?

- What are the perceptions and readiness of rural entrepreneurs towards engaging in online businesses?

- Is there any significant difference in the frequencies and skills in using ICT tools among the entrepreneurs after attending online training?

This paper reports the relevant findings pertaining to those questions and discusses factors that determine the online training modules' effectiveness.

\section{Research Methodology}

This section presents the design, sampling, instruments, data collection and the data analyses employed to answer the three research questions.

\section{Research Design}

Descriptive research design in the form of survey was employed in the study.

\section{Population and Sampling}

The division of Samarahan was chosen due to its proximity to the local Higher Institutions of Learning, such as UiTM, Universiti Malaysia Sarawak (UNIMAS) and Teachers Training Colleges, where it is considered that the location may facilitate knowledge transfers to the communities to upgrade further their standard of living via e-commerce or digitalized economy from agrobased industries. The main economic activity in Samarahan is agriculture. Hence, the target 
Lau, S. H. et al. Effectiveness of Online Training for Rural

Entrepreneurs During a Global Pandemic

population consisted of rural agro-based entrepreneurs registered with a local government agency, Samarahan Division Agriculture Office. The population consisted of 78 rural agro-based entrepreneurs registered with the agency. They included agro-based entrepreneurs from subdivisions of Kota Samarahan, Simunjan, and Asajaya. Random sampling method was used to select 31 rural agro-based entrepreneurs as sample for the study.

\section{Instruments}

Two sets of instruments were used in the study. The first set of instruments was a survey questionnaire adopted from Technology Acceptance Model (TAM) instrument from Davis (1989) and Adams et al. (1992). The questionnaire consisted of three sections. The first sections covered the demographic characteristics of the participants. The second section contained items related to challenges faced by the rural entrepreneurs and how they tried to overcome these challenges. It was aimed to collect data for the first research question. The third section aimed to collect data to answer the second research question, consisted of items related to their perception and readiness towards engaging in online businesses. In addition, participants were asked to suggest the type of training they need most.

Based on the training need analyses in the first survey, online training modules were designed and developed. The second set of questionnaire was the Entrance/Exit survey form to assess their frequency and skills in using nine (9) electronic devices or applications before and after attending the training. There is a total of 18 statements; 9 statements on the frequency of using the electronic devices or applications and another 9 statements on the skills of using them. Participants were required to indicate their degree of agreement using a 5-Likert scale (1Strongly disagree, 2-Disagree, 3-Unsure, 4-Agree, 5-Strongly agree) on the 18 statements.

\section{Data Collection Method}

The first set of questionnaire was administered after three months of the implementation of the first Movement Control Order (MCO) in April 2020. It was conducted via google form. Online training modules were designed for a month-long training programme. The modules consisted of four components based on the preceding needs-analysis findings: word processing, poster promotion, basic Excel business template, and digital marketing. The selected rural entrepreneurs were part of a specific Facebook group for the sole purpose of training. At the same time, a WhatsApp group was also formed to communicate with the participants actively. Facebook and WhatsApp were the main platforms as they are user friendly and most used by the participants. Training videos uploaded onto these platforms provide flexibility for participants to follow the lessons even outside their working or business hours. Discussions were held weekly via Google Meet. The entrance survey was conducted before the start of the first module, and the Exit survey was conducted one week after the end of the training programme. The analysis from the Entrance-Exit surveys was used to quantitatively measure the participants' level of understanding regarding the lessons provided.

\section{Data Analyses}

Data collected were analyzed using SPSS. The study employed both descriptive and inferential statistics. Descriptive statistics, including mean, median and mode, standard deviation and measure of skewness, were used to answer the first and second research questions. For the 
Lau, S. H. et al. Effectiveness of Online Training for Rural Entrepreneurs During a Global Pandemic

third research question, inferential statistics, Analysis of Variance (ANOVA) was used to determine whether there is a significant difference in the mean item scores before and after training. ANOVA tests were conducted at a 5\% significance level $(\alpha=0.05)$.

\section{Results and Discussion}

\section{Survey on Business During the MCO}

The surveys that followed were aimed to assess the readiness and acceptance of the entrepreneurs towards online businesses and identify their specific needs in coping with the pandemic. The businesses were substantially affected by the pandemic, as depicted by the survey results in Table 1, whereby $96.2 \%$ of respondents stated that their business activities were affected by the government's imposition of the Movement Control Order (MCO). 24 out of 26 respondents (92.3\%) said they face difficulties getting raw materials during the MCO period. However, only $42.3 \%$ of the respondents applied for financial assistance during the period.

Table 1. Effect of Movement Control Order (MCO) on business activities

\begin{tabular}{lccccccc}
\hline \multicolumn{1}{c}{ Statement } & \multicolumn{2}{c}{ Yes } & \multicolumn{2}{c}{ No } & \multicolumn{2}{c}{ Total } \\
\cline { 2 - 7 } & Count & $\begin{array}{c}\text { Percent } \\
(\%)\end{array}$ & Count & $\begin{array}{c}\text { Percent } \\
(\%)\end{array}$ & Count $\begin{array}{c}\text { Percent } \\
(\%)\end{array}$ \\
\hline $\begin{array}{l}\text { Is your business affected by the } \\
\text { MCO? }\end{array}$ & 25 & 96.2 & 1 & 3.8 & 26 & 100.0 \\
$\begin{array}{l}\text { Can your business operate } \\
\text { normally during the MCO? }\end{array}$ & 4 & 15.4 & 22 & 84.6 & 26 & 100.0 \\
$\begin{array}{l}\text { Does the MCO affect the supply of } \\
\text { raw materials for your business? }\end{array}$ & 24 & 92.3 & 2 & 7.7 & 26 & 100.0 \\
$\begin{array}{l}\text { Did you apply for any financial aid } \\
\text { during the MCO? }\end{array}$ & 11 & 42.3 & 15 & 57.7 & 26 & 100.0 \\
\hline
\end{tabular}

As the implementation of MCO has disrupted normal business activities, respondents were asked about their alternative source of income. The results in Table 2 showed that $26.9 \%$ of the respondents did not have any alternative source of income during that period. $15.4 \%$ of the respondents engaged in Cash on delivery (COD) and another $15.4 \%$ engaged in online sales. Others alternative incomes include selling other products (11.5\%), gardening (11.5\%), selling products from home (7.7\%), in villages (3.8\%), consignment to local shops (3.8\%) and involved in the food business (3.8\%).

Respondents were asked how they conducted their business during MCO, and the results are listed in Table 3. Of the total, $69.2 \%$ of the respondents conducted their businesses using online platforms such as WhatsApp, Instagram, Facebook, Grab, and Food panda. Only 23.1\% could still conduct their businesses face-to-face, while the remaining $7.7 \%$ conducted their sales through middlemen. 
Lau, S. H. et al. Effectiveness of Online Training for Rural Entrepreneurs During a Global Pandemic

Table 2. The alternative source of income during the MCO period

\begin{tabular}{lcc}
\hline $\begin{array}{l}\text { If you cannot operate your normal business, give } \\
\text { your alternative source of income. }\end{array}$ & Count & Percent (\%) \\
\hline None & 7 & 26.9 \\
Cash-on-delivery (COD) & 4 & 15.4 \\
Online selling & 4 & 15.4 \\
Selling other products & 3 & 11.5 \\
Farming & 3 & 11.5 \\
Sales from home & 2 & 7.7 \\
Sales in village & 1 & 3.8 \\
Food business & 1 & 3.8 \\
Consignment to local shops & 1 & 3.8 \\
\hline Total & 26 & 100.0 \\
\hline
\end{tabular}

Table 3. Mode of business during MCO

\begin{tabular}{lcc}
\hline State how you conduct business during the MCO. & Count & Percent (\%) \\
\hline Online platforms (WhatsApp, Instagram, Facebook, Grab, Food & 18 & 69.2 \\
Panda, etc.) & 6 & 23.1 \\
Direct sales/face-to face & 2 & 7.7 \\
Sales through middlemen & 26 & 100.0 \\
\hline Total & \\
\hline
\end{tabular}

Table 4 shows the comparison of monthly revenue of respondents before and during $\mathrm{MCO}$. The monthly revenue before MCO ranges from RM100 to RM20,000. However, during the MCO, the range drops to only from RM30 to RM1,000. There is also a drastic drop (72.6\%) in the mean monthly revenue from RM5,059.62 to RM1,387.69. In conclusion, MCO had significantly affected their revenues.

Table 4. Comparison of monthly revenue before and during MCO

\begin{tabular}{lccc}
\hline & \multicolumn{2}{c}{ Monthly revenue (RM) } & \multirow{2}{*}{ Percentage (\%) } \\
\cline { 2 - 3 } Minimum & \multicolumn{1}{c}{ Before MCO } & During MCO & \\
\cline { 2 - 4 } Maximum & 100 & 30 & $-70.0 \%$ \\
Mean & 20000 & 10000 & $-50.0 \%$ \\
Std. Deviation & 5059.62 & 1387.69 & $-72.6 \%$ \\
\hline
\end{tabular}

Respondents were also asked about the challenges faced during MCO, and the survey results are as shown in Table 5. From the survey, the greatest challenge was finding clients for their products, which $96.2 \%$ of respondents indicated. Other challenges in descending order are; covering operation cost (92.3\%), obtaining business model (88.5\%), getting supplies of raw 
Lau, S. H. et al. Effectiveness of Online Training for Rural Entrepreneurs During a Global Pandemic

materials (80.8\%), communication with clients (69.2\%), hiring workers (50.0\%) and paying business premise rental (38.5\%).

Table 5. Challenges during MCO

\begin{tabular}{|c|c|c|c|c|c|c|}
\hline \multirow[b]{2}{*}{$\begin{array}{l}\text { Since the MCO, I have faced } \\
\text { difficulty in }\end{array}$} & \multicolumn{2}{|c|}{ Yes } & \multicolumn{2}{|c|}{ No } & \multicolumn{2}{|c|}{ Total } \\
\hline & Count & $\begin{array}{l}\text { Percent } \\
(\%)\end{array}$ & Count & $\begin{array}{l}\text { Percent } \\
(\%)\end{array}$ & Count & $\begin{array}{l}\text { Percent } \\
(\%)\end{array}$ \\
\hline sourcing of raw materials & 21 & 80.8 & 5 & 19.2 & 26 & 100.0 \\
\hline getting customers & 25 & 96.2 & 1 & 3.8 & 26 & 100.0 \\
\hline communicate with customers & 18 & 69.2 & 8 & 30.8 & 26 & 100.0 \\
\hline getting workers & 13 & 50.0 & 13 & 50.0 & 26 & 100.0 \\
\hline delivering goods to customers & 21 & 80.8 & 5 & 19.2 & 26 & 100.0 \\
\hline getting capital for business & 23 & 88.5 & 3 & 11.5 & 26 & 100.0 \\
\hline $\begin{array}{l}\text { sustaining business operation } \\
\text { cost }\end{array}$ & 24 & 92.3 & 2 & 7.7 & 26 & 100.0 \\
\hline paying business rental & 10 & 38.5 & 16 & 61.5 & 26 & 100.0 \\
\hline
\end{tabular}

Almost all respondents stated that their business activities were affected by the government's imposition of MCOs since April 2020. Due to the difficulties faced during the MCO periods that have led to a substantial decrease in their income, some had applied for financial assistance. The disruption of normal business activities had forced a majority of the entrepreneurs to find alternative sources of income. At the same time more than half of the entrepreneurs had turned to online platforms in conducting their businesses. As mentioned by Maphalala et al. (2021), the pandemic situation has helped accelerated self-learning through the usage of online media.

In order to answer the second research question it is necessary to evaluate their usage of ICT tools during the pandemic, as it is related to their readiness for online business. Table 6 shows the survey on usage of ICT tools since MCO. Generally, respondents agreed that their frequency of usage of ICT tools except old handphones had increased since MCO as the total percentages of agreement (strongly agree and agree) are higher than the total percentages of disagreement (strongly disagree and disagree). The most notable increase in the frequency of usage is the usage of smartphones with $53.8 \%$ of the respondents strongly agreed, and another $42.3 \%$ agreed. Only one respondent, or $3.8 \%$ disagreed. Two other notable increases are the subscription of mobile data packages and social media usage, with $42.3 \%$ of the respondents strongly agree, and another $34.6 \%$ agree. There was also an increase in digital camera usage where $15.4 \%$ of the respondents strongly agreed, and another $42.3 \%$ agreed. These are consistent with the increase in the frequency of use of smartphones. Other ICT tools in decreasing order of usage are laptops and scanners, with $15.4 \%$ of the respondents strongly agree and another $26.9 \%$ agree, printers (11.5\% strongly agree, $26.9 \%$ agree) and desktop computers (3.8\% strongly agree, $26.9 \%$ agree). For the usage of old handphones, $15.4 \%$ of the respondents strongly disagree, and another $34.6 \%$ disagree the usage had increased since MCO. Only $15.4 \%$ of the respondents strongly agree, and another $15.4 \%$ agree the use of old handphones has increased since MCO. 
Lau, S. H. et al. Effectiveness of Online Training for Rural Entrepreneurs During a Global Pandemic

Table 6. Usage of ICT tools since MCO

\begin{tabular}{|c|c|c|c|c|c|c|c|}
\hline $\begin{array}{l}\text { Since the } \mathrm{MCO}, \text { I have } \\
\text { frequently been using }\end{array}$ & $\begin{array}{c}\text { Count } \\
\text { Percent (\%) }\end{array}$ & 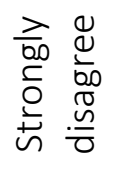 & $\begin{array}{l}\Phi \\
\Phi \\
\frac{1}{00} \\
0 \\
\stackrel{\omega}{0} \\
\square\end{array}$ & $\begin{array}{l}\stackrel{0}{J} \\
\stackrel{5}{\subseteq} \\
د\end{array}$ & $\frac{\mathscr{Q}}{\alpha}$ & 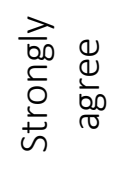 & $\begin{array}{l}\overline{\widetilde{T}} \\
\stackrel{0}{0} \\
\end{array}$ \\
\hline \multirow[t]{2}{*}{ old handphone } & Count & 4 & 9 & 5 & 4 & 4 & 26 \\
\hline & Percent (\%) & 15.4 & 34.6 & 19.2 & 15.4 & 15.4 & 100 \\
\hline \multirow[t]{2}{*}{ smartphone } & Count & 1 & 0 & 0 & 11 & 14 & 26 \\
\hline & Percent (\%) & 3.8 & 0.0 & 0.0 & 42.3 & 53.8 & 100 \\
\hline \multirow[t]{2}{*}{ desktop computer } & Count & 4 & 2 & 12 & 7 & 1 & 26 \\
\hline & Percent (\%) & 15.4 & 7.7 & 46.2 & 26.9 & 3.8 & 100 \\
\hline \multirow[t]{2}{*}{ laptop } & Count & 4 & 1 & 10 & 7 & 4 & 26 \\
\hline & Percent (\%) & 15.4 & 3.8 & 38.5 & 26.9 & 15.4 & 100 \\
\hline \multirow[t]{2}{*}{ internet data package } & Count & 0 & 1 & 5 & 9 & 11 & 26 \\
\hline & Percent (\%) & 0.0 & 3.8 & 19.2 & 34.6 & 42.3 & 100 \\
\hline \multirow[t]{2}{*}{ digital camera } & Count & 3 & 1 & 7 & 11 & 4 & 26 \\
\hline & Percent (\%) & 11.5 & 3.8 & 26.9 & 42.3 & 15.4 & 100 \\
\hline \multirow[t]{2}{*}{ digital scanner } & Count & 3 & 2 & 10 & 7 & 4 & 26 \\
\hline & Percent (\%) & 11.5 & 7.7 & 38.5 & 26.9 & 15.4 & 100 \\
\hline \multirow[t]{2}{*}{ printer } & Count & 4 & 1 & 11 & 7 & 3 & 26 \\
\hline & Percent (\%) & 15.4 & 3.8 & 42.3 & 26.9 & 11.5 & 100 \\
\hline \multirow[t]{2}{*}{ social media } & Count & 0 & 1 & 5 & 9 & 11 & 26 \\
\hline & Percent (\%) & 0.0 & 3.8 & 19.2 & 34.6 & 42.3 & 100 \\
\hline
\end{tabular}

Respondents, in general, agreed that their skills in handling ICT tools had improved since the $\mathrm{MCO}$ as the total percentages of agreement (strongly agree and agree) are higher than or equal to the total percentages of disagreement (strongly disagree and disagree), as presented in Table 7. There is a close association between the survey results on skills in handling ICT tools and the survey results on the frequency of usage of ICT tools. Skills in handling ICT tools increase with the frequency of their usage. A total of $34.6 \%$ of the respondents strongly agree, and another $46.2 \%$ agree their skills in handling smartphones improved since the MCO. There are also notable improvements in skills in managing social media (34.6\% strongly agree, $46.2 \%$ agree) and mobile data plan subscriptions (26.9\% strongly agree, $50.0 \%$ agree). The percentage of respondents who agree their handing skills had improved for other ICT tools in descending order are; printers (11.5\% strongly agree, $34.6 \%$ agree), digital cameras (7.7\% strongly agree, $34.6 \%$ agree), laptops (11.5\% strongly agree, $30.8 \%$ agree), desktop computers (38.5\% agree), old handphones (15.4\% strongly agree, $15.4 \%$ agree) and digital scanners (11.5\% strongly agree, $19.2 \%$ agree). 
Lau, S. H. et al. Effectiveness of Online Training for Rural Entrepreneurs During a Global Pandemic

Table 7. Skills in handling ICT tools since MCO

\begin{tabular}{|c|c|c|c|c|c|c|c|}
\hline $\begin{array}{l}\text { Since the MCO, I have } \\
\text { improved my skills in } \\
\text { handling }\end{array}$ & $\begin{array}{l}\text { Frequency } \\
\text { Percent (\%) }\end{array}$ & 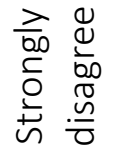 & 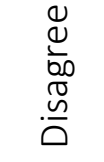 & 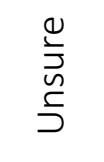 & 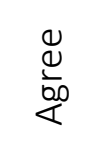 & 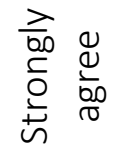 & $\begin{array}{l}\bar{\pi} \\
\stackrel{0}{0} \\
\vdash\end{array}$ \\
\hline \multirow[t]{2}{*}{ old handphone } & Count & 3 & 5 & 10 & 4 & 4 & 26 \\
\hline & Percent (\%) & 11.5 & 19.2 & 38.5 & 15.4 & 15.4 & 100 \\
\hline \multirow[t]{2}{*}{ smartphone } & Count & 2 & 0 & 3 & 12 & 9 & 26 \\
\hline & Percent (\%) & 7.7 & 0.0 & 11.5 & 46.2 & 34.6 & 100 \\
\hline \multirow[t]{2}{*}{ desktop computers } & Count & 1 & 4 & 11 & 10 & 0 & 26 \\
\hline & Percent (\%) & 3.8 & 15.4 & 42.3 & 38.5 & 0.0 & 100 \\
\hline \multirow[t]{2}{*}{ laptop } & Count & 2 & 2 & 11 & 8 & 3 & 26 \\
\hline & Percent (\%) & 7.7 & 7.7 & 42.3 & 30.8 & 11.5 & 100 \\
\hline \multirow[t]{2}{*}{ Internet data package } & Count & 1 & 1 & 4 & 13 & 7 & 26 \\
\hline & Percent (\%) & 3.8 & 3.8 & 15,4 & 50.0 & 26.9 & 100 \\
\hline \multirow[t]{2}{*}{ digital camera } & Count & 2 & 2 & 11 & 9 & 2 & 26 \\
\hline & Percent (\%) & 7.7 & 7.7 & 42.3 & 34.6 & 7.7 & 100 \\
\hline \multirow[t]{2}{*}{ digital scanner } & Count & 3 & 2 & 13 & 5 & 3 & 26 \\
\hline & Percent (\%) & 11.5 & 7.7 & 50.0 & 19.2 & 11.5 & 100 \\
\hline \multirow[t]{2}{*}{ printer } & Count & 2 & 2 & 10 & 9 & 3 & 26 \\
\hline & Percent (\%) & 7.7 & 7.7 & 38.5 & 34.6 & 11.5 & 100 \\
\hline \multirow[t]{2}{*}{ social media } & Count & 1 & 1 & 3 & 12 & 9 & 26 \\
\hline & Percent (\%) & 3.8 & 3.8 & 11.5 & 46.2 & 34.6 & 100 \\
\hline
\end{tabular}

All respondents expressed their interest in engaging in online businesses and perceived online business as important (Table 8 ). A total of $96.2 \%$ of the respondents view online businesses as able to increase their revenue besides conventional business. $80.8 \%$ of the respondents expressed their readiness to engage in online business on a part-time basis. Only 61.5\% express their readiness to engage in online business on a full-time basis. However, only $38.5 \%$ of the respondents have adequate ICT facilities to engage in online business.

Towards the end of the survey, respondents were asked about the suggested training programmes they wish to participate in. The results in Table 9 shows that $38.5 \%$ of the respondents stated training programmes related to video promotion. $26.9 \%$ of the respondents chose training on how to effectively use social media, while another $23.1 \%$ wished to attend training on dropships. The remaining $11.5 \%$ preferred to join training on digital marketing.

All respondents expressed their interest in engaging online businesses, and a large majority of them viewed online business as important means of increasing their revenue besides conventional business. In general, the respondents agreed that their usage and skills in handling ICT tools have increased since the MCO. Consequently, a high percentage of the respondents stated that they are ready to engage in online business either part-time or full-time. The findings agree with previous studies that reported entrepreneurs' necessary and significant transition to 
Lau, S. H. et al. Effectiveness of Online Training for Rural Entrepreneurs During a Global Pandemic

online learning and online business due to the COVID-19 pandemic restrictions (Akpan et al., 2020; Govindarajan \& Srivastava, 2020).

Table 8. Perception and readiness towards engaging in online businesses

\begin{tabular}{|c|c|c|c|c|c|c|}
\hline \multirow[b]{2}{*}{ After the MCO, will you } & \multicolumn{2}{|c|}{ Yes } & \multicolumn{2}{|c|}{ No } & \multicolumn{2}{|c|}{ Total } \\
\hline & Count & $\begin{array}{l}\text { Percent } \\
(\%)\end{array}$ & Count & $\begin{array}{c}\text { Percent } \\
(\%)\end{array}$ & Count & $\begin{array}{l}\text { Percent } \\
(\%)\end{array}$ \\
\hline $\begin{array}{l}\text { be more interested in online } \\
\text { business? }\end{array}$ & 26 & 100 & 0 & 0.0 & 26 & 100.0 \\
\hline feel online business is important? & 26 & 100 & 0 & 0.0 & 26 & 100.0 \\
\hline $\begin{array}{l}\text { be ready to engage in online } \\
\text { business part-time? }\end{array}$ & 21 & 80.8 & 5 & 19.2 & 26 & 100.0 \\
\hline $\begin{array}{l}\text { be ready to engage in online } \\
\text { business full time? }\end{array}$ & 16 & 61.5 & 10 & 38.5 & 26 & 100.0 \\
\hline $\begin{array}{l}\text { have adequate ICT facilities to do } \\
\text { online business? }\end{array}$ & 10 & 38.5 & 16 & 61.5 & 26 & 100.0 \\
\hline $\begin{array}{l}\text { feel that online business will } \\
\text { increase your revenue beside } \\
\text { conventional business? }\end{array}$ & 25 & 96.2 & 1 & 3.8 & 26 & 100.0 \\
\hline
\end{tabular}

Table 9. Suggested training programmes

\begin{tabular}{lcc}
\hline Type of training & Frequency & Percentage \\
\hline Video promotion & 10 & 38.5 \\
Dropships & 6 & 23.1 \\
Effective usage of social media & 7 & 26.9 \\
Digital marketing (example in Shopee/Lazada) & 3 & 11.5 \\
\hline Total & 26 & 100.0 \\
\hline
\end{tabular}

\section{Online Training}

This section reports the survey results on the frequency and skills in using selected electronic devices or applications before and after one month of online training. The data is aimed to find out the significant difference in the frequencies and skills in using ICT tools among the entrepreneurs after online training. A total of 31 entrepreneurs had participated. At the beginning of the training, participants were required to fill an online entrance survey form to assess their frequency and skills in using 9 electronic devices or applications, namely old handphone, smartphone, desktop computer, laptop, data package subscription, digital camera, scanner, printer and social media. Towards the end of the training, participants were asked to fill similar sets of online exit survey. Each participant was assessed twice using the same instrument resulting in pairs of observations.

To gauge the effectiveness of the online training, the results of the entrance and exit surveys were compared. Paired sample t-test was conducted to determine whether there is any 
Lau, S. H. et al. Effectiveness of Online Training for Rural Entrepreneurs During a Global Pandemic

significant difference between the means of the entrance and exit survey. The tests were conducted by using a $5 \%$ level of significance $(\alpha=0.05)$.

Table 10 and Table 11 show the paired samples statistics and paired samples test for frequency of using old handphone, smartphone and desktop computer. Based on Table 10, the mean on the frequency of usage in the Exit survey was higher than in the Entrance survey for all the three electronic devices (old handphone, smartphone and desktop computer). This indicated that their frequency of using these three devices had generally increased after attending online training. Although there is an increase in the frequency of usage, further paired samples t-test in Table 11 shows that the increase was not statistically significant. The $p$-values for frequency of usage for old handphone $\left(\frac{0.344}{2}=0.72\right)$, smartphone $\left(\frac{0.130}{2}=0.065\right)$ and computer $\left(\frac{0.354}{2}=0.177\right)$ were all greater than $\alpha=0.05$.

Table 10. Paired samples statistics for frequency of using old handphone, smartphone and desktop computer

\begin{tabular}{llllcc}
\hline Frequency of using & & Mean & $N$ & Std. Deviation & $\begin{array}{c}\text { Std. Error } \\
\text { Mean }\end{array}$ \\
\hline Old handphone & Exit & 2.7097 & 31 & 1.27000 & 0.22810 \\
& Entrance & 2.5484 & 31 & 1.02758 & 0.18456 \\
Smartphone & Exit & 4.3871 & 31 & 0.91933 & 0.16512 \\
Desktop computer & Entrance & 4.0968 & 31 & 1.22079 & 0.21926 \\
& Exit & 2.9032 & 31 & 1.01176 & 0.18172 \\
& Entrance & 2.7742 & 31 & 1.08657 & 0.19515 \\
\hline
\end{tabular}

Table 11. Paired samples test for frequency of using old handphone, smartphone and computer

\begin{tabular}{|c|c|c|c|c|c|c|c|c|c|}
\hline \multirow{3}{*}{$\begin{array}{l}\text { Frequency } \\
\text { of using }\end{array}$} & & \multicolumn{5}{|c|}{ Paired Differences } & \multirow{3}{*}{$\mathrm{t}$} & \multirow{3}{*}{$d f$} & \multirow{3}{*}{$\begin{array}{l}\text { Sig. } \\
(2- \\
\text { tailed })\end{array}$} \\
\hline & & \multirow[t]{2}{*}{ Mean } & \multirow[t]{2}{*}{$\begin{array}{c}\text { Std. } \\
\text { Deviation }\end{array}$} & \multirow[t]{2}{*}{$\begin{array}{l}\text { Std. } \\
\text { Error } \\
\text { Mean }\end{array}$} & \multicolumn{2}{|c|}{$\begin{array}{c}\text { 95\% Confidence } \\
\text { Interval of the } \\
\text { Difference }\end{array}$} & & & \\
\hline & & & & & Lower & Upper & & & \\
\hline $\begin{array}{l}\text { Old hand } \\
\text { phone }\end{array}$ & $\begin{array}{l}\text { Exit- } \\
\text { Entrance }\end{array}$ & 0.16129 & 0.93441 & 0.16782 & $\begin{array}{c}- \\
0.18145\end{array}$ & 0.50403 & 0.961 & 30 & 0.344 \\
\hline $\begin{array}{l}\text { Smart } \\
\text { phone }\end{array}$ & $\begin{array}{l}\text { Exit- } \\
\text { Entrance }\end{array}$ & 0.29032 & 1.03902 & 0.18661 & $\begin{array}{c}- \\
0.09079\end{array}$ & 0.67144 & 1.556 & 30 & 0.130 \\
\hline $\begin{array}{l}\text { Desktop } \\
\text { computer }\end{array}$ & $\begin{array}{l}\text { Exit- } \\
\text { Entrance }\end{array}$ & 0.12903 & 0.76341 & 0.13711 & $\begin{array}{c}- \\
0.15099\end{array}$ & 0.40905 & 0.941 & 30 & 0.354 \\
\hline
\end{tabular}

Tables 12 and 13 show the paired samples statistics and paired sample test for frequency of using laptops, data package subscription, and digital camera. Table 12 showed the mean values for the Exit survey were higher than the mean values for the Entrance survey for laptop, data 
Lau, S. H. et al. Effectiveness of Online Training for Rural Entrepreneurs During a Global Pandemic

package subscription and digital camera. This indicated that the frequency of using these three devices had generally increased after attending online training. However, the paired samples ttest in Table 13 shows that the increase was not statistically significant. The $p$-values for frequency of usage for laptop $\left(\frac{0.851}{2}=0.4255\right)$, data package subscription $\left(\frac{0.282}{2}=0.141\right)$ and digital camera $\left(\frac{0.199}{2}=0.0995\right)$ were all greater than $\alpha=0.05$.

Table 12. Paired samples statistics for frequency of using laptop, data package subscription and digital camera

\begin{tabular}{llcccc}
\hline Frequency of using & & Mean & N & Std. Deviation & Std. Error Mean \\
\hline \multirow{2}{*}{ Laptop } & Exit & 3.1613 & 31 & 1.18594 & 0.21300 \\
Data package & Entrance & 3.1290 & 31 & 1.25809 & 0.22596 \\
subscription & Exit & 4.0000 & 31 & 1.00000 & 0.17961 \\
\multirow{2}{*}{ Digital camera } & Entrance & 3.8387 & 31 & 1.15749 & 0.20789 \\
& Exit & 3.3871 & 31 & 1.17409 & 0.21087 \\
& Entrance & 3.1290 & 31 & 1.20394 & 0.21623 \\
\hline
\end{tabular}

Table 13. Paired samples test for frequency of using laptop, data package subscription and digital camera

\begin{tabular}{|c|c|c|c|c|c|c|c|c|c|}
\hline \multirow{3}{*}{$\begin{array}{l}\text { Frequency } \\
\text { of using }\end{array}$} & & \multicolumn{5}{|c|}{ Paired Differences } & \multirow{3}{*}{$\mathrm{t}$} & \multirow{3}{*}{ df } & \multirow{3}{*}{$\begin{array}{c}\text { Sig. } \\
\text { (2-tailed) }\end{array}$} \\
\hline & & \multirow[t]{2}{*}{ Mean } & \multirow[t]{2}{*}{$\begin{array}{c}\text { Std. } \\
\text { Deviation }\end{array}$} & \multirow{2}{*}{$\begin{array}{l}\text { Std. } \\
\text { Error } \\
\text { Mean }\end{array}$} & \multicolumn{2}{|c|}{$\begin{array}{l}\text { 95\% Confidence } \\
\text { Interval of the } \\
\text { Difference }\end{array}$} & & & \\
\hline & & & & & Lower & Upper & & & \\
\hline Laptop & $\begin{array}{l}\text { Exit- } \\
\text { Entrance }\end{array}$ & 0.03226 & 0.94812 & 0.17029 & $\begin{array}{c}- \\
0.31551\end{array}$ & 0.38003 & 0.189 & 30 & 0.851 \\
\hline $\begin{array}{l}\text { Data } \\
\text { package } \\
\text { subscription }\end{array}$ & $\begin{array}{l}\text { Exit- } \\
\text { Entrance }\end{array}$ & 0.16129 & 0.82044 & 0.14735 & $\begin{array}{c}- \\
0.13965\end{array}$ & 0.46223 & 1.095 & 30 & 0.282 \\
\hline $\begin{array}{l}\text { Digital } \\
\text { camera }\end{array}$ & $\begin{array}{l}\text { Exit- } \\
\text { Entrance }\end{array}$ & 0.25806 & 1.09446 & 0.19657 & $\begin{array}{c}- \\
0.14339\end{array}$ & 0.65952 & 1.313 & 30 & 0.199 \\
\hline
\end{tabular}

Table 14 and Table 15 show the paired samples statistics and paired sample test for frequency of using the scanner, printer and social media. A similar trend was observed where the mean values for the Exit survey were higher than the mean values for the Entrance survey, as shown in Table 14. However, the paired samples t-test in Table 15 shows that the increase in the frequency of usage of the three devices or applications was not statistically significant. The $p-$ values for frequency of usage for scanner, printer, and social media were $\left(\frac{0.174}{2}=0.087\right)$, $\left(\frac{0.787}{2}=0.3935\right)$ and $\left(\frac{0.153}{2}=0.0765\right)$ respectively. These $p$-values were all greater than $\alpha=0.05$. Although participants reported an increase in the frequency of using all the 9 
Lau, S. H. et al. Effectiveness of Online Training for Rural Entrepreneurs During a Global Pandemic

electronic devices or applications at the end of the online training session, the increases in the reported frequencies were not statistically significant at a $5 \%$ level of significance.

Table 14. Paired samples statistics for frequency of using the scanner, printer and social media

\begin{tabular}{llllcc}
\hline $\begin{array}{l}\text { Frequency } \\
\text { using }\end{array}$ & of & Mean & $\mathrm{N}$ & Std. Deviation & $\begin{array}{c}\text { Std. Error } \\
\text { Mean }\end{array}$ \\
\hline Scanner & Exit & 3.1935 & 31 & 1.13782 & 0.20436 \\
& Entrance & 2.9355 & 31 & 1.23654 & 0.22209 \\
\multirow{2}{*}{ Printer } & Exit & 3.0645 & 31 & 1.12355 & 0.20180 \\
\multirow{2}{*}{ Social media } & Entrance & 3.0323 & 31 & 1.22431 & 0.21989 \\
& Exit & 4.0645 & 31 & 0.92864 & 0.16679 \\
& Entrance & 3.7742 & 31 & 1.23044 & 0.22099 \\
\hline
\end{tabular}

Table 15. Paired samples test for frequency of using the scanner, printer and social media

\begin{tabular}{|c|c|c|c|c|c|c|c|c|c|}
\hline \multirow{3}{*}{$\begin{array}{l}\text { Frequency of } \\
\text { using }\end{array}$} & & \multicolumn{5}{|c|}{$\begin{array}{l}\text { Paired Samples Test } \\
\text { Paired Differences }\end{array}$} & \multirow{3}{*}{$\mathrm{t}$} & \multirow{3}{*}{$d f$} & \multirow{3}{*}{$\begin{array}{l}\text { Sig. } \\
(2- \\
\text { tailed })\end{array}$} \\
\hline & & \multirow[t]{2}{*}{ Mean } & \multirow[t]{2}{*}{$\begin{array}{c}\text { Std. } \\
\text { Deviation }\end{array}$} & \multirow{2}{*}{$\begin{array}{l}\text { Std. } \\
\text { Error } \\
\text { Mean }\end{array}$} & \multicolumn{2}{|c|}{$\begin{array}{l}\text { 95\% Confidence } \\
\text { Interval of the } \\
\text { Difference }\end{array}$} & & & \\
\hline & & & & & Lower & Upper & & & \\
\hline Scanner & $\begin{array}{l}\text { Exit- } \\
\text { Entrance }\end{array}$ & 0.25806 & 1.03175 & 0.18531 & $\begin{array}{c}- \\
0.12039\end{array}$ & 0.63651 & 1.393 & 30 & 0.174 \\
\hline Printer & $\begin{array}{l}\text { Exit- } \\
\text { Entrance }\end{array}$ & 0.03226 & 0.65746 & 0.11808 & $\begin{array}{c}- \\
0.20890\end{array}$ & 0.27342 & 0.273 & 30 & 0.787 \\
\hline Social media & $\begin{array}{l}\text { Exit- } \\
\text { Entrance }\end{array}$ & 0.29032 & 1.10132 & 0.19780 & $\begin{array}{c}- \\
0.11364\end{array}$ & 0.69429 & 1.468 & 30 & 0.153 \\
\hline
\end{tabular}

A similar paired samples t-test was conducted on the responses to 9 remaining statements on the improvement in the 'participants' skills in using the 9 electronic devices or applications. The results are shown in Table 16 and Table 17. The results were similar and consistent with the findings on responses to the 9 previous statements. All means for the Exit survey were higher or similar than the corresponding means for the Entrance survey. This indicated that generally, participants perceived their skills in using the electronic devices or applications improved at the end of the online training session. However, paired samples t-test showed that the perceived improvement in skills was not statistically significant at a 5\% level of significance. Table 16 shows the paired sample statistics on skills in using old handphone, smartphone and desktop computer. The mean values for the Exit survey were higher than the mean values for the Entrance survey. However, the paired samples t-Test show that improvement in skills was not statistically significant at $\alpha=0.05$ (Table 17). The $p$-values were all greater than $\alpha=0.05$. 
Lau, S. H. et al. Effectiveness of Online Training for Rural Entrepreneurs During a Global Pandemic

Table 16. Paired samples statistics on the skill in using old handphone, smartphone and computer

\begin{tabular}{llllcc}
\hline Skills in using & & Mean & N & Std. Deviation & $\begin{array}{c}\text { Std. Error } \\
\text { Mean }\end{array}$ \\
\hline Old handphone & Exit & 3.1613 & 31 & 1.06761 & 0.19175 \\
& Entrance & 3.0000 & 31 & 1.15470 & 0.20739 \\
Smart phone & Exit & 4.0000 & 31 & 1.09545 & 0.19675 \\
& Entrance & 3.9355 & 31 & 1.12355 & 0.20180 \\
Desktop computer & Exit & 3.2903 & 31 & 0.90161 & 0.16193 \\
& Entrance & 3.0968 & 31 & 0.83086 & 0.14923 \\
\hline
\end{tabular}

Table 17. Paired samples test on the skill in using old handphone, smartphone and computer

\section{Paired Differences}

\begin{tabular}{|c|c|c|c|c|c|c|c|c|c|}
\hline \multirow[t]{2}{*}{$\begin{array}{l}\text { Skills in } \\
\text { using }\end{array}$} & & \multirow[t]{2}{*}{ Mean } & \multirow[t]{2}{*}{$\begin{array}{c}\text { Std. } \\
\text { Deviation }\end{array}$} & \multirow[t]{2}{*}{$\begin{array}{l}\text { Std. } \\
\text { Error } \\
\text { Mean }\end{array}$} & \multicolumn{2}{|c|}{$\begin{array}{c}\text { 95\% Confidence } \\
\text { Interval of the } \\
\text { Difference }\end{array}$} & & \multirow[t]{2}{*}{$d f$} & \multirow[t]{2}{*}{$\begin{array}{l}\text { Sig. } \\
(2- \\
\text { tailed })\end{array}$} \\
\hline & & & & & Lower & Upper & & & \\
\hline $\begin{array}{l}\text { Old hand } \\
\text { phone }\end{array}$ & $\begin{array}{l}\text { Exit- } \\
\text { Entrance }\end{array}$ & 0.16129 & 1.12833 & 0.20265 & $\begin{array}{c}- \\
0.25258\end{array}$ & 0.57516 & 0.796 & 30 & 0.432 \\
\hline $\begin{array}{l}\text { Smart } \\
\text { phone }\end{array}$ & $\begin{array}{l}\text { Exit- } \\
\text { Entrance }\end{array}$ & 0.06452 & 1.26321 & 0.22688 & $\begin{array}{c}- \\
0.39883\end{array}$ & 0.52787 & 0.284 & 30 & 0.778 \\
\hline $\begin{array}{l}\text { Desktop } \\
\text { computer }\end{array}$ & $\begin{array}{l}\text { Exit- } \\
\text { Entrance }\end{array}$ & 0.19355 & 0.90992 & 0.16343 & $\begin{array}{c}- \\
0.14021\end{array}$ & 0.52731 & 1.184 & 30 & 0.246 \\
\hline
\end{tabular}

Table 18 shows the paired samples statistics on skills in using laptop, data package subscription and digital camera. The mean values for the Exit survey were either higher than or similar to the mean values for the Entrance survey. Results for paired samples t-Test in Table 19 show that skills improvement was not statistically significant at $\alpha=0.05$. All the $p$-values were greater than $\alpha=0.05$.

Table 18. Paired samples statistics on skill in using laptop, data package subscription and digital camera

\begin{tabular}{llcccc}
\hline Skills in using & & Mean & $\mathrm{N}$ & Std. Deviation & Std. Error Mean \\
\hline \multirow{2}{*}{ Laptop } & Exit & 3.4516 & 31 & .96051 & 0.17251 \\
\multirow{2}{*}{ Data package } & Entrance & 3.2258 & 31 & 1.02338 & 0.18380 \\
subscription & Exit & 3.7742 & 31 & 1.11683 & 0.20059 \\
\multirow{2}{*}{ Digital camera } & Entrance & 3.7742 & 31 & 1.02338 & 0.18380 \\
& Exit & 3.3871 & 31 & 0.80322 & 0.14426 \\
& Entrance & 3.2903 & 31 & 1.00643 & 0.18076 \\
\hline
\end{tabular}


Lau, S. H. et al. Effectiveness of Online Training for Rural Entrepreneurs During a Global Pandemic

Table 19. Paired samples test on skill in using laptop, data package subscription and digital camera

\begin{tabular}{|c|c|c|c|c|c|c|c|c|c|}
\hline \multirow{3}{*}{ Skills in using } & \multicolumn{6}{|c|}{ Paired Differences } & \multirow{3}{*}{$\mathrm{t}$} & \multirow{3}{*}{$d f$} & \multirow{3}{*}{$\begin{array}{c}\text { Sig. } \\
\text { (2-tailed) }\end{array}$} \\
\hline & & \multirow[t]{2}{*}{ Mean } & \multirow[t]{2}{*}{$\begin{array}{c}\text { Std. } \\
\text { Deviation }\end{array}$} & \multirow{2}{*}{$\begin{array}{l}\text { Std. } \\
\text { Error } \\
\text { Mean }\end{array}$} & \multicolumn{2}{|c|}{$\begin{array}{c}\text { 95\% Confidence } \\
\text { Interval of the } \\
\text { Difference }\end{array}$} & & & \\
\hline & & & & & Lower & Upper & & & \\
\hline Laptop & $\begin{array}{l}\text { Exit- } \\
\text { Entrance }\end{array}$ & 0.22581 & 1.05545 & 0.18956 & -0.16134 & 0.61295 & 1.191 & 30 & 0.243 \\
\hline $\begin{array}{l}\text { Data package } \\
\text { subscription }\end{array}$ & $\begin{array}{l}\text { Exit- } \\
\text { Entrance }\end{array}$ & 0.00000 & 0.96609 & 0.17352 & -0.35437 & 0.35437 & 0.000 & 30 & 1.000 \\
\hline Digital camera & $\begin{array}{l}\text { Exit- } \\
\text { Entrance }\end{array}$ & 0.09677 & 1.27423 & 0.22886 & -0.37062 & 0.56416 & 0.423 & 30 & 0.675 \\
\hline
\end{tabular}

Table 20 shows the paired samples statistics on skills in using the scanner, printer and social media. The mean values for the Exit survey were also higher than the mean values for the Entrance survey. Even so, the results for paired samples t-Test in Table 21 show improvement in skills were not statistically significant at $\alpha=0.05$. All the $p$-values were greater than $\alpha=0.05$.

Table 20. Paired samples statistics on skill in using the scanner, printer and social media

\begin{tabular}{lllccc}
\hline Skills in using & & Mean & $\mathrm{N}$ & Std. Deviation & Std. Error Mean \\
\hline \multirow{2}{*}{ Scanner } & Exit & 3.3871 & 31 & 0.98919 & 0.17766 \\
& Entrance & 3.0968 & 31 & 1.07563 & 0.19319 \\
\multirow{2}{*}{ Printer } & Exit & 3.5484 & 31 & 0.88840 & 0.15956 \\
& Entrance & 3.2581 & 31 & 1.03175 & 0.18531 \\
\multirow{2}{*}{ Social media } & Exit & 3.9677 & 31 & 1.01600 & 0.18248 \\
& Entrance & 3.9355 & 31 & 1.03071 & 0.18512 \\
\hline
\end{tabular}

Table 21. Paired samples test on skill in using the scanner, printer and social media

\begin{tabular}{|c|c|c|c|c|c|c|c|c|c|}
\hline \multirow{3}{*}{ Skills in using } & \multicolumn{6}{|c|}{ Paired Differences } & \multirow{3}{*}{$\mathrm{t}$} & \multirow{3}{*}{ df } & \multirow{3}{*}{$\begin{array}{l}\text { Sig. } \\
(2- \\
\text { tailed })\end{array}$} \\
\hline & & \multirow[t]{2}{*}{ Mean } & \multirow[t]{2}{*}{$\begin{array}{c}\text { Std. } \\
\text { Deviation }\end{array}$} & \multirow[t]{2}{*}{$\begin{array}{l}\text { Std. } \\
\text { Error } \\
\text { Mean }\end{array}$} & \multicolumn{2}{|c|}{$\begin{array}{c}\text { 95\% Confidence } \\
\text { Interval of the } \\
\text { Difference }\end{array}$} & & & \\
\hline & & & & & Lower & Upper & & & \\
\hline Scanner & $\begin{array}{l}\text { Exit- } \\
\text { Entrance }\end{array}$ & 0.29032 & 1.21638 & 0.21847 & $\begin{array}{c}- \\
0.15585\end{array}$ & 0.73649 & 1.329 & 30 & 0.194 \\
\hline Printer & $\begin{array}{l}\text { Exit- } \\
\text { Entrance }\end{array}$ & 0.29032 & 1.07062 & 0.19229 & $\begin{array}{c}- \\
0.10239\end{array}$ & 0.68303 & 1.510 & 30 & 0.142 \\
\hline Social media & $\begin{array}{l}\text { Exit- } \\
\text { Entrance }\end{array}$ & 0.03226 & 1.13970 & 0.20470 & $\begin{array}{c}- \\
0.38579\end{array}$ & 0.45030 & 0.158 & 30 & 0.876 \\
\hline
\end{tabular}


Lau, S. H. et al. Effectiveness of Online Training for Rural Entrepreneurs During a Global Pandemic

The participants had indicated that their frequency and skills of using the electronic devices or applications had generally improved after the training, the increment or improvement was not statistically significant. This indicated that while the participants, to some extent, benefited from the online training provided, it did not have a significant impact on them. This finding was expected due to several constraints faced by the participants to fully engage in the online training. Apart from having to manage their businesses and coping with the pandemic situation, they faced problems of inadequate facilities for online learning, particularly lack of good network coverage, internet availability in their respective locations, and difficulty in using smart devices.

\section{Conclusion}

Almost all respondents of the surveys were affected by the COVID-19 pandemic and the Movement Control Orders (MCOs) imposed by the government in Malaysia since April 2020. Among the challenges faced by the rural entrepreneurs during those times were a significant decrease in their income, disruption of normal business activities forcing most of them to engage in alternative businesses. Amid the difficulties, the entrepreneurs were more exposed to usage of ICT tools as they became necessary for doing business during the pandemic. The online training modules which were tailored to the specific needs of the entrepreneurs were found to be interesting and helpful by the participants. This is partly attributed to the combination of the medium used (online videos, Facebook, and WhatsApp), which provided participants with flexible learning time. However, there was no significant impact due to the various constraints faced by the entrepreneurs in online learning. In view of these factors, the effectiveness of future online training modules may be improved by extension of the training program in the form of continuous engagement via social media platforms. This will enable trainers to monitor the participants' progress for a further period of 6 - 12 months and provide advisory services to enrich their knowledge and online business skills.

\section{References}

Abdul Rashid, S. M. R. (2016). Capability of ICT in Improving the Achievements of Rural Women Entrepreneurs in Malaysia. Journal of Social Sciences and Humanities, 11(2), 78-103.

Adams, D. A., Nelson, R. R., \& Todd, P. A. (1992). Perceived usefulness, ease of use, and usage of information technology: A replication. MIS Quarterly, 16(2), 227-247. https://doi.org/10.2307/249577

Akpan, I. J., Soopramanien, D., \& Kwak, D-H. (2020): Cutting-edge technologies for small business and innovation in the era of COVID-19 global health pandemic, Journal of Small Business \& Entrepreneurship, 1-11. https://doi.org/10.1080/08276331.2020.1799294

AlDahdouh, A.A. (2019). Individual Learning Experience in Connectivist Environment: A Qualitative Sequence Analysis. International Journal of Research in Education and Science (IJRES), 5(2), 488-509.

Ali, G. E., \& Magalhaes, R. (2008). Barriers to implementing e-learning: A Kuwaiti case study. International Journal of Training and Development 12(1), 36-53. https://doi.org/10.1111/j.1468-2419.2007.00294.x 
Lau, S. H. et al. Effectiveness of Online Training for Rural Entrepreneurs During a Global Pandemic

Altowairiki, N. (2021). Online Collaborative Learning: Analyzing the Process through Living the Experience. International Journal of Technology in Education (IJTE), 4(3), 413-427. https://doi.org/10.46328/ijte.95

Atilgan, D. \& Tukel, Y. (2021). Social capital and satisfaction with life during the COVID-19 pandemic: A case study on coaches. International Journal on Social and Education Sciences (IJonSES), 3(2), 342-359. https://doi.org/10.46328/ijonses.185

Batmang, B., Sultan, M., Azis, A., \& Gunawan, F. (2021). Perceptions of Pre-Service Teachers on Online Learning during the COVID-19 Pandemic. International Journal of Education in Mathematics, Science, and Technology (IJEMST), 9(3), 449-461. https://doi.org/10.46328/ijemst.1595

Caldeira, M., Serrano, A., Quaresma, R., Pedron, C., \& Romão, M. (2012). Information and communication technology adoption for business benefits: A case analysis of an integrated paperless system. International Journal of Information Management, 32(2), 196-202. https://doi.org/10.1016/j.ijinfomgt.2011.12.005

Davis, F. D. (1989). Perceived usefulness, perceived ease of use, and user acceptance of information technology. MIS Quarterly, 13(3), 319-340. https://doi.org/10.2307/249008

Demosthenous, G., Panaoura, A., \& Eteokleous N. (2020). The Use of Collaborative Assignment in Online Learning Environments: The Case of Higher Education. International Journal of Technology in Education and Science (IJTES), 4(2), 108-117.

ElSaheli-Elhage, R. (2021). Access to Students and Parents and Levels of Preparedness of Educators during the COVID-19 Emergency Transition to e-Learning. International Journal on Studies in Education (IJOnSE), 3(2), 61-69.

Gnaniah, J., Yeo, A., Songan, P., Zen, H. and Ab Hamid, K. (2004). A Comparison on the Implementation Approaches for the e-Bario and e-Bedian Projects. In H.M. Khalid, M.G. Helander, A.W.Yeo (Eds). Work with Computing Systems. Kuala Lumpur: Damai Sciences. pp. $286-291$.

Govindarajan, V. \& Srivastava A. (2020). What the shift to virtual learning could mean for the future of higher ed. Harvard Business Review, March 31, 2020.

Hitt, L. M., \& Brynjolfsson, E. (1996). Productivity, Business Profitability, and Consumer Surplus: Three Different Measures of Information Technology Value. MIS Quarterly 20 (2), $121-$ 142. https://doi.org/10.2307/249475

Horn, C., \& Rennie, E. (2018). Digital access, choice and agency in remote Sarawak. Telematics and Informatics, 35(7), 1935-1948. https://doi.org/10.1016/j.tele.2018.06.006

Hu, H. \& Huang, F. (2022). Application of Universal Design for Learning into Remote English Education in Australia amid COVID-19 Pandemic. International Journal on Studies in Education (IJonSE), 4(1), 55-69. https://doi.org/10.46328/ijonse.59

K. Selvarajah T. K., \& Hussin, H. (2017). E-learning readiness on Bumiputera SME's intention for adoption of online entrepreneurship training in Malaysia. Management, 7(1), 35-39. 
Lau, S. H. et al. Effectiveness of Online Training for Rural Entrepreneurs During a Global Pandemic

Kalimullina, O., Tarman, B. \& Stepanova, I. (2021). Education in the Context of Digitalization and Culture: Evolution of the Teacher's Role, Pre-pandemic Overview. Journal of Ethnic and Cultural Studies, 8(1), 226-238. DOI: http://dx.doi.org/10.29333/ejecs/629

Kara, S. (2021). An Investigation of Visual Arts Teachers' Attitudes towards Distance Education in the Time of COVID-19. International Journal on Social and Education Sciences (IJonSES), 3(3), 576-588. https://doi.org/10.46328/ijonses.246

Kibici, V. B. (2021). Analysis of Music Teachers' Job Satisfaction and COVID-19 Anxiety Levels. International Journal on Social and Education Sciences (IJonSES), 3(4), 752-767. https://doi.org/10.46328/ijonses.275

Kilincer, O. (2021). An Investigation of Pre-service Music Teachers' Attitudes towards Online Learning during the COVID-19 Pandemic. International Journal of Technology in Education and Science (IJTES), 5(4), 587-600. https://doi.org/10.46328/ijtes.304

Korkmaz, G. \& Toraman, Ç. (2020). Are We Ready for the Post-COVID-19 Educational Practice? An Investigation into What Educators Think as to Online Learning. International Journal of Technology in Education and Science (IJTES), 4(4), 293-309.

Laudon, K. C., and Laudon, J. P. (2019). Management Information Systems: Managing the Digital Firm. 16th ed. Harlow, UK: Pearson Education Limited.

Maphalala, M. C., Mkhasibe, R. G. \& Mncube, D. W. (2021). Online Learning as a Catalyst for Self-directed Learning in Universities during the COVID-19 Pandemic, Research in Social Sciences and Technology, 6(2), 233-248. https://doi.org/10.46303/ressat.2021.25

Matarirano, O., Gqokonqana, O. \& Yeboah, A. (2021). Students' Responses to Multi-Modal Emergency Remote Learning During COVID-19 in a South African Higher Institution. Research in Social Sciences and Technology, 6(2),199-218. https://doi.org/10.46303/ressat.2021.19

Mukhopadhyay, T., Kekre, S., \& Kalathur, S. (1995). Business value of information technology: a study of electronic data interchange. MIS quarterly, 137-156. https://doi.org/10.2307/249685

Paudyal, G. R., \& Rana, K. (2021). How University Lecturers and Students Interpret Opportunities and Challenges of Online Mode of Learning. International Journal of Research in Education and Science (IJRES), 7(4), 1006-1022. https://doi.org/10.46328/ijres.2383

Restuati, M., Nasution, M. Y., Pulungan, A. S. S., Pratiwi, N., \& Safirah, B. (2021). Improvement Efforts for Student Learning Outcomes and Motivation using Edmodo during the COVID19 Pandemic. International Journal of Education in Mathematics, Science, and Technology (IJEMST), 9(4), 614-624. https://doi.org/10.46328/ijemst.1974

Smith, A. D., \& Correa, J. (2005). Value-Added Benefits of Technology: E-Procurement and eCommerce Related to the Health Care Industry. International Journal of Health Care Quality Assurance, 18 (6), 458-473. https://doi.org/10.1108/09526860510619444

Sousa, M. J., Carmo, M., Gonçalves, A. C., Cruz, R., \& Martins, J. M. (2019). Creating knowledge and entrepreneurial capacity for HE students with digital education methodologies: 
Lau, S. H. et al. Effectiveness of Online Training for Rural Entrepreneurs During a Global Pandemic

Differences in the perceptions of students and entrepreneurs. Journal of Business Research, 94(1), 227-240. https://doi.org/10.1016/j.jbusres.2018.02.005

Thompson, V. L. \& McDowell, Y. L. (2019). A case study comparing student experiences and success in an undergraduate course offered through online, blended, and face-to-face instruction. International Journal of Education in Mathematics, Science and Technology (IJEMST), 7(2), 116-136.

Turkina, E. (2018). The importance of networking to entrepreneurship: Montreal's artificial intelligence cluster and its born-global firm element Al. Journal of Small Business \& Entrepreneurship, 30 (1), 1-18. https://doi.org/10.1080/08276331.2017.1402154

Welsh, E.T., Wanberg, C.R., Brown, K.G., \& Simmering, M.J. (2003). E-learning: Emerging uses, empirical results and future directions. International Journal of Training and Development, 7(4), 245-258. https://doi.org/10.1046/j.1360-3736.2003.00184.x

Williams, T.K., McIntosh, R.W., \& Russell, W.B. (2021). Equity in distance education during COVID-19. Research in Social Sciences and Technology, 6(1), 1-24. https://doi.org/10.46303/ressat.2021.1

Xhelili, P., Ibrahimi, E., Rruci, E., \& Sheme, K. (2021). Adaptation and Perception of Online Learning during COVID-19 Pandemic by Albanian University Students. International Journal on Studies in Education (IJonSE), 3(2), 103-111. 